\title{
Whole-body DWI in patients with lymphoma: imaging findings, pitfalls, and limitations
}

\author{
Alain Rahmouni ${ }^{*}$, Sarah Toledano ${ }^{1}$, Chieh Lin $^{2}$, Emmanuel Itti $^{3}$, Corinne Haioun ${ }^{4}$, Alain Luciani ${ }^{5}$ \\ From International Cancer Imaging Society (ICIS) 14th Annual Teaching Course \\ Heidelberg, Germany. 9-11 October 2014
}

Whole body (WB) imaging plays an essential role in the management of lymphoma patients, including defining the full extent of the disease at baseline, allowing for an accurate staging and therefore an adapted treatment strategy, assessing treatment response and detecting relapse. Contrast-enhanced computed tomography (CT) has long been the imaging technique most commonly used for staging and follow up of malignant lymphoma, using International Working Group (IWG) criteria [1]. However, CT lacks functional and metabolic information, compromising identification of disease in non-enlarged lymph nodes or other organs, as well as sufficient contrast in certain organs as for example the spleen or bone marrow. In 2007, IWG response criteria were revised, incorporating Positron Emission Tomography (PET) with 18-fluorodeoxyglucose (FDG) information [2], thus combining metabolic information and anatomical data of the CT resulting in a higher accuracy than the both imaging modalities taken separately [3].

Diffusion Weighted Magnetic Resonance Imaging (DW-MRI) probes noninvasively the random microscopic motion of water molecules in the body, reflecting cellularity and cell membrane integrity. Because of their high cellularity and high nuclear-to-cytoplasm ratio, lymphomas have a lower apparent diffusion coefficient (ADC) than other tumors [4]. WB-DW-MRI allows both anatomical information, as well as functional and quantitative evaluation of tumor sites, thanks to the extraction of the apparent diffusion coefficient (ADC). At staging, lymphoma lesions have low ADC value except necrotic areas.

Recent studies comparing whole-body DWI to PETCT have demonstrated the potential role of whole-body

\footnotetext{
* Correspondence: alain.rahmouni@hmn.aphp.fr

'Departement d'Imagerie Médicale, AP-HP, CHU Henri Mondor, Faculte de Medecine, Universite Paris-Est Creteil, France

Full list of author information is available at the end of the article
}

DWI in routine lymphoma patient care but included only a small number of patients. Using the DWIBS technique (diffusion weighted imaging with background body signal suppression), Abdulqadhr et al. compared whole-body DWI and PET/CT at staging with an agreement in the Ann Arbor stage for $90.3 \%$ of patients [5]. Based on ADC analysis, Lin et al showed an agreement at baseline in 93\% of patients [4]. Response assessment is necessary during therapy to readapt treatment strategy if necessary, and to document a complete remission at the end of treatment. After treatment, an increase in ADC value of residual masses has been demonstrated [6]. Recent technical breakthroughs in MRI technology such as echo-planar imaging (EPI), high gradient amplitudes, combined phased-array surface coils covering the patient, and parallel imaging, have drastically improved patient comfort and acceptance for whole body MRI $[7,8]$, making this technique feasible in clinical routine, illustrating the need for radiologists to get familiar with this technique. As a result, WB-DW-MRI with ADC mapping has become a promising tool for lymphoma staging and re-staging, and response assessment.

Based on our 4-years experience with WB-DW-MRI applied in Hodgkin and diffuse large B-cell lymphoma patients together with 18FDG-PET/CT, our objective is to offer radiologists the information required to optimize acquisition whole body DWI parameters on both 1.5 and 3T MR systems. We will expose the spectrum of imaging findings and discuss the pitfalls, limitations, and potential challenges of WB-DW-MRI in caring for lymphoma patients.

\footnotetext{
Authors' details

'Departement d'Imagerie Médicale, AP-HP, CHU Henri Mondor, Faculte de Medecine, Universite Paris-Est Creteil, France. ${ }^{2}$ Department of Nuclear Medicine and Molecular Imaging Center, Chan Gung Memorial Hospital and Chang Gung University College of Medicine, Taoyuan, Taiwan. ${ }^{3}$ Departement de Medecine Nucleaire, AP-HP, CHU Henri Mondor, Faculte de Medecine,
} 
Universite Paris-Est Creteil, France. ${ }^{4}$ Departement d'Hematologie Clinique, AP-HP, CHU Henri Mondor, Faculte de Medecine, Universite Paris-Est Creteil,

France. ${ }^{5}$ TBC.

Published: 9 October 2014

\section{References}

1. Cheson BD, Horning SJ, Coiffier B, Shipp MA, Fisher RI, Connors JM, et al: Report of an international workshop to standardize response criteria for non-Hodgkin's lymphomas. NCl Sponsored International Working Group. J Clin Oncol 1999, 17:1244-1253.

2. Cheson BD, Pfistner B, Juweid ME, Gascoyne RD, Specht L, Horning SJ, et al: Revised Response Criteria for Malignant Lymphoma. J Clin Oncol 2007, 25:579-586.

3. Haioun C, Itti E, Rahmouni A, Brice P, Rain JD, Belhadj K, Gaulard P, Garderet L, Lepage E, Reyes F, Meignan M: [18F]fluoro-2-deoxy-D-glucose positron emission tomography (FDG-PET) in aggressive lymphoma: an early prognostic tool for predicting patient outcome. Blood 2005, 106:1376-1381.

4. Lin C, Luciani A, Itti E, El-Gnaoui T, Vignaud A, Beaussart P, et al: Wholebody diffusion-weighted magnetic resonance imaging with apparent diffusion coefficient mapping for staging patients with diffuse large Bcell lymphoma. Eur Radiol 2010, 20:2027-2038.

5. Abdulqadhr G, Molin D, Astrom G, Suurkula M, Johansson L, Hagberg H, et al: Whole-body diffusion-weighted imaging compared with FDG-PET/ CT in staging of lymphoma patients. Acta Radiol 2011, 52:173-80.

6. Lin C, Itti E, Luciani A, Zegai B, Lin S-J, Kuhnowski F, Rahmouni A: Wholebody diffusion-weighted imaging with apparent diffusion coefficient mapping for treatment response assessment in patients with diffuse large B-cell lymphoma: pilot study. Invest Radiol 2011, 46:341-349.

7. Koh D-M, Collins DJ: Diffusion-Weighted MRI in the Body: Applications and Challenges in Oncology. AJR 2007, 188:1622-1635.

8. Padhani AR, Liu G, Koh D-M, Chenevert TL, Thoeny HC, Takahara T, et al: Diffusion-weighted magnetic resonance imaging as a cancer biomarker: consensus and recommendations. Neoplasia 2009, 11:102-125.

doi:10.1186/1470-7330-14-S1-022

Cite this article as: Rahmouni et al.: Whole-body DWI in patients with lymphoma: imaging findings, pitfalls, and limitations. Cancer Imaging 2014 14(Suppl 1):O22.

\section{Submit your next manuscript to BioMed Central and take full advantage of:}

- Convenient online submission

- Thorough peer review

- No space constraints or color figure charges

- Immediate publication on acceptance

- Inclusion in PubMed, CAS, Scopus and Google Scholar

- Research which is freely available for redistribution 